Гараненко Т. P.

\title{
РОЗРОБКА КОНСТРУКТОРСЬКО-ТЕХНОЛОГІЧНИХ РІШЕНЬ ВИГОТОВЛЕННЯ ПОРОЖНИСТОЇ ЛОПАТКИ 3 ТИТАНОВИХ СПЛАВІВ
}

Сучасні тенденції розвитку конструкції авіаційних двигунів показують, що одним із напрямків забезпечення їх ефективності являється використання великогабаритних лопаток вентилятора зниженої маси. Одним з перспективних напрямків розвитку конструкції таких лопаток є використання лопаток порожнистого типу.

Лопатка компресора ГТД повинна відповідати таким вимогам, як малому лобовому опору, великій підйомній силі, високій втомній і механічній міцності, ресурсу і надійності, визначними вібраційними характеристиками для запобігання виникненню небезпечних резонансних коливань лопаток на робочих режимах двигуна. На лопатку при експлуатації впливають значні знакозмінні і циклічні навантаження, а діючі відцентрові і газові сили викликають великі напруження розтягнення, кручення і згинання. Мінімальні відхилення геометричних форм і розмірів профілю пера від розрахункових призводить до зменшення ККД компресора, втрати потужності і до зниження економічності двигуна [1].

На основі узагальнення етапів еволюції конструкції вентиляторної лопатки побудована класифікація технічних рішень конструкції вентиляторної лопатки. Основною задачею удосконалення вентиляторних лопаток $є$ зниження маси пера лопатки за рахунок конструктивно-технологічних рішень при збереженні експлуатаційних параметрів (властивостей статичної та динамічної міцності).

Розроблений класифікатор є основою для вибору конструктивно-технологічних рішень при проектуванні лопатки. Кожен з класів має свої різновидності форм та елементів конструкції. Найбільш перспективним по масовій ефективності є лопатки 4 класу - порожнисті лопатки з листовим наповнювачем [2].

Одним важливим питанням при створенні конструкції порожнистої лопатки є забезпечення міцності. Конструкція порожнистої лопатки залежить від навантажень (механічних та температурних), які виникають при роботі ГТД. Використання програмних продуктів допомагає спроектувати конструкцію складної форми та великими габаритами. Аналітично вирішувати задачу складно внаслідок складної геометрії конструкції та граничних умов. Проведення розрахунку на міцність необхідно для встановлювання динамічних характеристик, стійкість до автоколивань, визначення найбільш небезпечного перерізу, діючих навантажень та комплексного проектування геометрії конструкції [3-6].

У ряді опублікованих статей [7-10] проводилася чисельна оцінка напруженодеформованого стану порожнистої вентиляторної лопатки з двоякою опуклістю і без закрутки перерізів по радіусу. Це сильно спрощує створення математичної моделі і дозволяє проводити порівняльний аналіз впливу на напруженість конструкції внутрішньої гофри.

Мета роботи - розробка процесу формоутворення в ізотермічних умовах фрагменту конструкції порожнистої лопатки з титанових сплавів для газотурбінних двигунів на основі розробленого конструкторсько-технологічного класифікатора та проведеного розрахунку на міцність.

Чисельне дослідження міцності конструкції складається з етапів:

1. побудова фізичної моделі;

2. побудова математичної моделі;

3. метод дослідження математичної моделі;

4. аналіз отриманих результатів.

В якості фізичної моделі взята вентиляторна лопатка діючого ГТД. Для проведення порівняльного аналізу на початку розраховувалася модель вентиляційної лопатки конкретного 
профілю, що знаходиться в льотній експлуатації. Отримані результати були прийняті в якості критерію при проведенні подальшого чисельного моделювання (рис. 1).
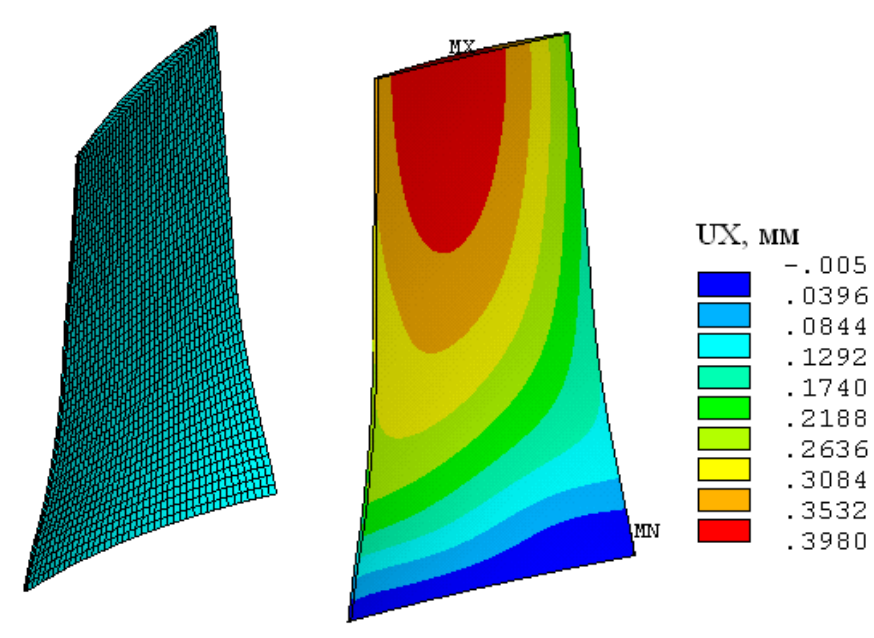

6

a

моделі

вентиляційної

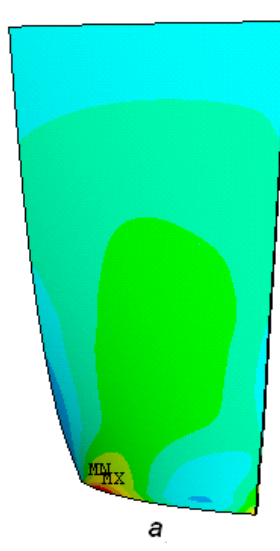

B

що знаходиться в льотній експлуатації:

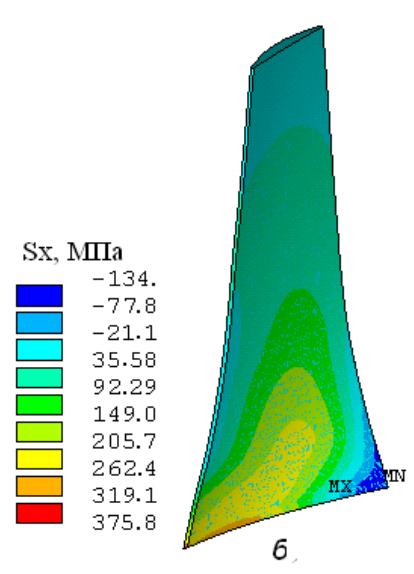

a - кінцева-елементна модель пера робочої лопатки; б - радіальні переміщення пера робочої лопатки вентилятора; в - радіальні напруження пера робочої лопатки вентилятора (а - спинка, б - корито)

Перехід до моделювання порожнистої лопатки здійснено згідно з розробленою технологією. Спинка і корито пера відповідають чинній лопатці. Організовано об'єми і згенерована кінцево-елементна сітка елементом SOLID186, з тієї ж густотою розбивки, як і в працюючій лопатці (рис. 2).

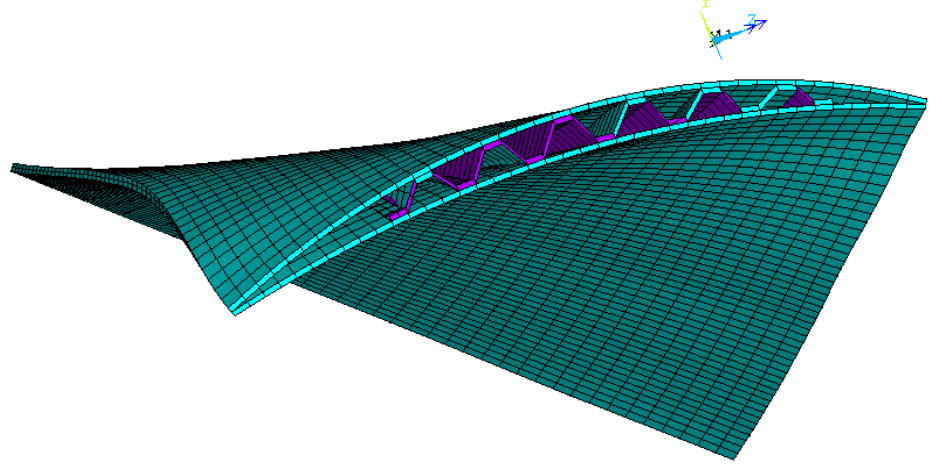

Рис. 2. Модель полого пера робочої лопатки вентилятора, кінцева-елементна сітка

Наповнювач, «гофра», максимально наближений по геометрії до профілю пера. Об'єм «гофри» розділений на найпростіші об'єми для полегшення генерації кінцево-елементної сітки. Труднощі при генерації сітки виникли через сильну закрученість пера лопатки по висоті і зменшення товщини лопатки зі збільшенням радіуса перерізу лопатки. Якість сітки впливає на результати розрахунку.

Модель виконана відповідно робочим кресленням робочої вентиляторної лопатки. Подальший перехід до моделі порожнистої лопатки здійснювався безпосередньо можливостями розрахункового комплексу ANSYS, використовуючи з імпортованого об'єму поверхні спинки і корита. Створення математичної моделі плоскої порожнистої лопатки з гофрою виконувалося в системі розрахункового комплексу ANSYS [11]. 
Чисельне математичне моделювання передбачає максимальну відповідність моделі до натурного об'єкту. Матеріал вентиляторної лопатки - титановий сплав ВТ6 з механічними

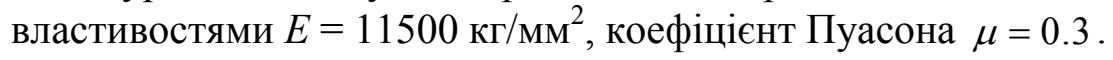

При генерації 3-D кінцево-елементної сітки використовувався елемент 2-ого порядку Solid186 (20-ти вузловий гексаедр). Розмір елемента вибирався з умови пропорційності по трьом напрямкам та визначався розміром товщини профілю суцільної лопатки. При переході до порожнистої лопатки строго дотримувалося збереження густини сітки, тобто постійність розміру кінцевого елемента, з метою можливості проведення порівняльного аналізу результатів розрахунку варіантів моделей. При генерації кінцево-елементної сітки орієнтувалися виключно на створенні впорядкованої сітки, чому сприяло наявність правильних об'ємів гексаедрів. При генерації сітки в наповнювачі порожнистої лопатки використовували процедуру VolumeSweep.

Хвостову частину лопатки з математичної моделі виключили, для спрощення. Граничні умови в вигляді закріплення прикладали на кореневому перерізі пера. У перспективі, при налагодженні кінцево-елементної порожнистої моделі пера лопатки, як навантажень можна розглядати робочий тиск на перо, робочу частоту обертання і робоче температурне поле.

Виконувався статичний та модальний аналіз для кожного варіанту математичної моделі. При виконанні модального аналізу виконувалося визначення форм і частот перших 3-х форм власних коливань. Граничні умови у вигляді закріплення прикладали на корневий переріз пера. Робочий розподілений тиск прикладався на поверхню корита пера лопатки. Задавалася робоча частота обертів 610 1/с.

Друга проблема створення кінцево-елементної моделі полого пера 3 «гофрою» це забезпечення спільної роботи корпусу пера і «гофри». На практиці спільна робота корпусу i «гофри» забезпечується контактним точковим зварюванням. На прикладі чисельного експерименту, тобто розрахунку математичної моделі, можна сказати, що цими операціями (точкового зварювання і наступних технологічних операцій), що забезпечує спільність обшивки і наповнювача, необхідно приділяти підвищену увагу. Інакше деякі складові конструкції працюють самостійно, що неприпустимо. Як моделюванням, так і реальними технологічними процесами забезпечити ідеальну спільність конструкції складно.

Розрахунок моделі пера з наповнювачем - «гофрою» показав що в даному випадку виконане чисельне моделювання недосконале і потребує значного доопрацювання, як і технологічний процес 3 виготовлення фізичної моделі для експерименту пов'язаний з реальними труднощами. Для оцінки рівня деформацій і напружень було прийнято рішення перейти до формування плоскої порожнистої моделі з «гофрою».

Створено математичну модель плоскої порожнистої лопатки з «гофрою». Розміри моделі відповідають кресленням деталі для виготовлення з подальшим дослідженням. Дана модель значно простіше в чисельному виконанні і в практичному реальному виконанні.

Модель виконується 3 титанового листа, розмірами $290 \times 158$ мм. Висота «гофри» прийнята рівною середній товщині реальної лопатки вентилятора.

Товщина листа 0,6 мм. У математичної моделі виконана умовно точкове зварювання «гофри» і листа. Якість зварювання на реальній моделі вимагає особливої уваги і ретельного виконання.

По нижній кромці моделі (кореневий переріз лопатки) організовано закріплення моделі в усіх напрямках, імітуючи закріплення реальної моделі в затискачі. По верхній кромці, відповідно периферійному перерізу лопатки, прикладено контурне навантаження розтягування $\left(\sigma_{\text {конт }}=230 \mathrm{MПа).} \mathrm{Дане} \mathrm{навантаження} \mathrm{відтворює} \mathrm{діючу} \mathrm{центробіжну} \mathrm{силу} \mathrm{в} \mathrm{полі} \mathrm{обер-}\right.$ тання лопатки з частотою $n=6020$ об/хв. На площу, яка відповідає кориту лопатки прикладено розподілений тиск від впливу повітряного потоку. Поле тиску відповідає реальній робочій лопатці вентилятора $(0,004 \ldots$.. 0,014 МПа). 
Для оцінки НДС моделі виконані статичний і динамічний аналіз математичної моделі програмним розрахунковим комплексом ANSYS. Результати статичного аналізу представлені у вигляді розподілу переміщень, радіальних, згинаючих, дотичних (від кручення) і еквівалентних напружень (рис. 3).

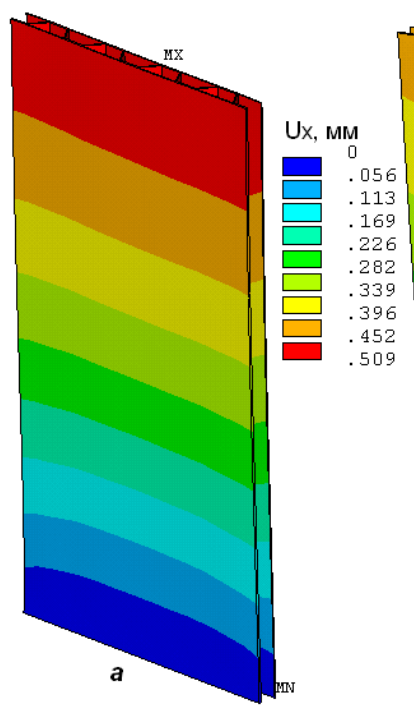

a

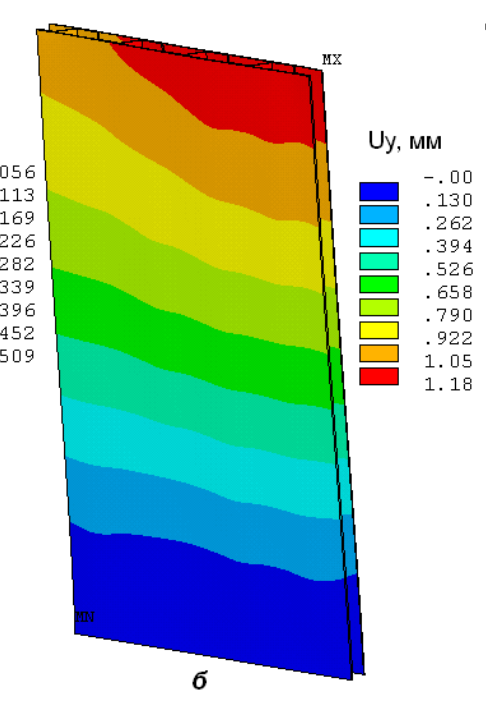

6

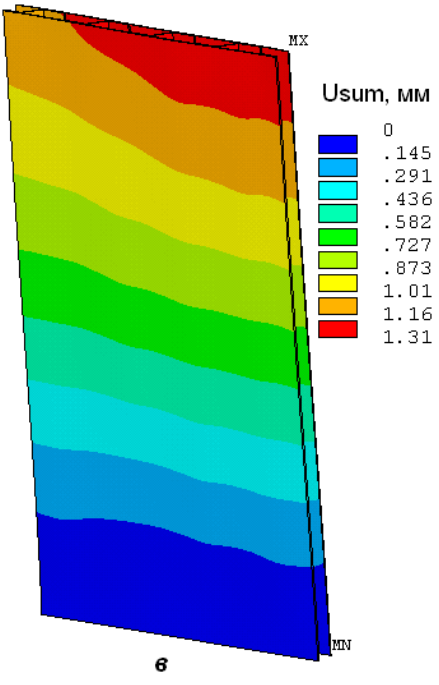

B

Рис. 3. Розподіл радіальних (а), осьових (б) і сумарних переміщень (в) пера порожнистої плоскою моделі з «гофрою»

Несиметричність розподілу напружень на «кориті» і «спинці» моделі плоскої лопатки можна пояснити різною жорсткістю пластин, отриманої від несиметричної взаємодії пластин 3 «гофрою».

Величини осьових напружень незначні, - як наслідок прикладеного на поверхню корита тиску. Можна помітити, що вигин сприймає «гофра», тоді як пластини корита і спинки не навантажені.

Рівень напружень в моделі плоскої порожнистої лопатки від прикладених навантажень невисокий, нижче, ніж в суцільній робочій лопатці (рис. 4).

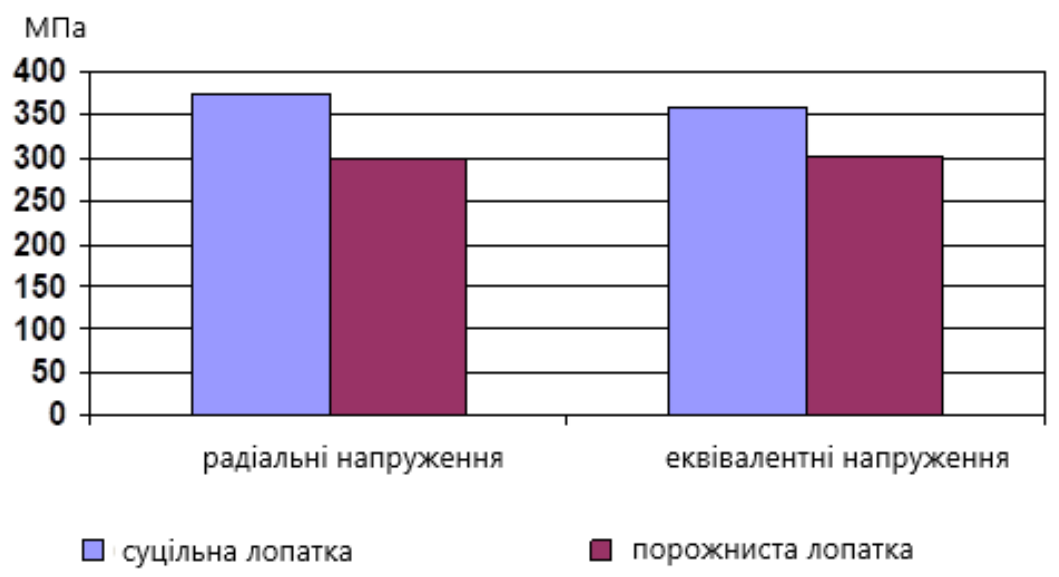

Рис. 4. Порівняльний аналіз рівня напружень вихідної і плоскої порожнистої лопаток

Рівень напружень в порожнистій лопатці нижче ніж в вихідній. Напруження в кореневому перерізі обумовлені відцентровою силою лопатки в умовах обертання з частотою ротора. Величина відцентрової сили прямо пропорційна масі лопатки. Тому напруження в вихідній 
лопатці, маса якої більша маси порожнистої лопатки будуть вищі напружень порожнистої лопатки, це показує розрахунок. Перехід на порожнисту лопатку обумовлено прагненням знизити рівень напружень відповідальної деталі ГТД.

Виконаний модальний аналіз моделі пера порожнистої плоскої лопатки визначив форми і частоти власних коливань.

Для визначення опору втоми лопаток рівень змінних напружень в них повинен бути достатньо низьким. Підвищення змінних напружень виникають в лопатках на резонансних режимах, коли частоти зовнішніх збуджуючих сил співпадають з однією з власних частот коливань лопатки. Практичне значення мають частоти від 1000-1500 Гц. На стадії проектування важливо визначити власні частоти коливань лопаток, особливо першу (нижчу) частоту згинальних коливань, яка пов'язана з деформацією лопатки відносно осі мінімальної жорсткості [12]. При обертанні на вентиляторну лопатку діють відцентрові сили, які створюють розтягнення лопатки, цим підвищують частоту власних коливань.

Модальний аналіз показує, що у пера порожнистої плоскої моделі лопатки вентилятора частоти 3-х перших форм власних коливань значно вище, ніж у пера вихідної суцільної лопатки вентилятора [13].

Величина частот власних коливань об'єкта визначається геометрією об'єкта та матеріалом об'єкта. На величини власних коливань впливає зміна профілю лопатки. Головне, щоб зміна геометрії лопатки привела до великого ступеня стискування повітря. Порядок величин 3-х перших частот власних коливань типовий для даної вентиляторної лопатки. Величини частот низькі і забезпечують відсутність резонансу в робочому діапазоні частот обертання ротора. Різниця в величинах частот власних коливань вихідної лопатки та порожнистої обумовлена різницею в геометрії.

На основі розрахунків була вибрана конструкція порожнистої лопатки. Поперечний переріз лопатки представлено на рис. 5. Відпрацювання технології отримання типового перерізу грунтується на отриманні порожнистої лопатки обмеженої довжини експериментально. Формоутворення порожнистої лопатки доцільно виконувати на фрагменті, якщо задовольняється умова співвідношення довжини до максимальної ширини більше трьох $\frac{L}{B} \geq 3$.

В $[14,15,16]$ запропоновані способи виготовлення порожнистої лопатки, на основі яких була розроблена технологія виготовлення порожнистих лопаток, яка грунтується на поєднанні двох процесів зварювання під тиском і формування в ізотермічних умовах.

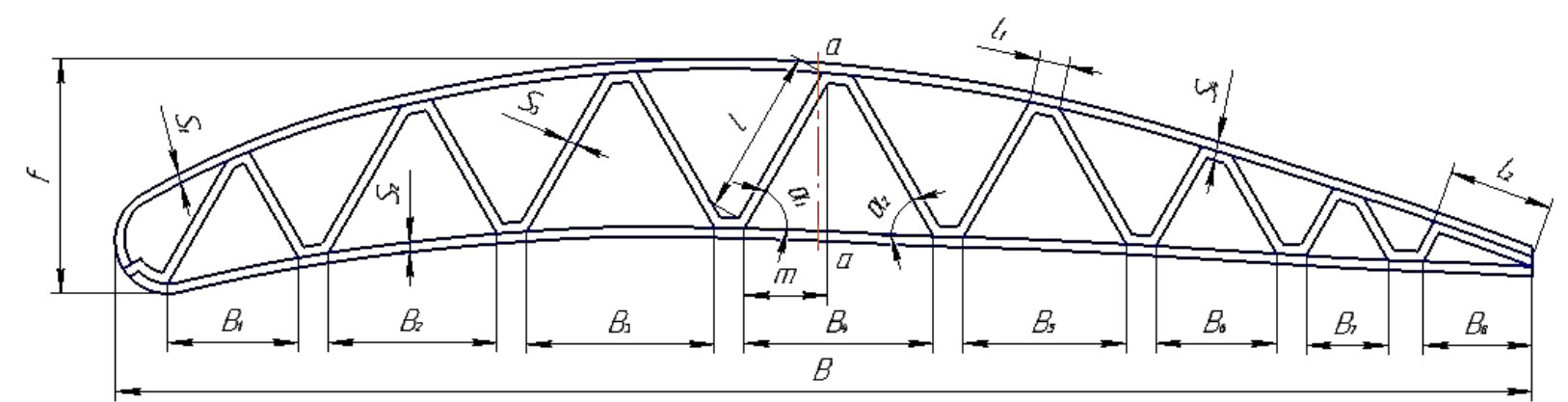

Рис. 5. Поперечній переріз фрагменту металевої порожнистої лопатки

В якості листового матеріалу, для виготовлення лопатки, використовувати титановий сплав - ОТ4-0. Для отримання вихідних заготовок з розміром зерна на порядок менше, промисловий лист піддають додатковій деформації прокаткою. Подрібнення зерна забезпечить активний перебіг процесу зерно граничного проковзування при формоутворенні, та знизить кількість дефектів в зонах з'єднання обшивки з наповнювачем. 3 промислового листа товщиною 0,5 мм вирізують три заготовки: дві для обшивки і одну для наповнювача.

Наведена нижча структура технологічного процесу виготовлення порожнистої лопатки вентилятора полягає в наступному (рис. 6): 
1. Нанести захисне покриття нітрид бора на поверхні ділянок заготовок обшивок і наповнювача, які не повинні дифузійна зварюватися, використовуючи трафарет;

2. Ділянки, які піддаються дифузійному з'єднанню, механічно зачистити;

3. Зібрати заготовки обшивок і наповнювача, штуцер в пакет;

4. Герметизувати пакет по кромкам;

5. Нагріти пакет до температури дифузійного зварювання і здійснити з'єднання заготовок;

6. Надати цільній конструкційній заготовці, отриманій після дифузійного зварювання шляхом нагрівання до температури ізотермічного формування, аеродинамічний профіль з формуванням корита спинки лопатки;

7. Подати в порожнину формоутворення установки робоче середовище для створення тиску, необхідного для ізотермічного формування;

8. Здійснити ізотермічне формування до отримання порожнистого пера лопатки і формування ребер жорсткості;

9. Зміцнення поверхневого шару лопатки методом поверхневого пластичного деформування - сталевими кульками в поле потужного ультразвуку;

10. Контроль якості.
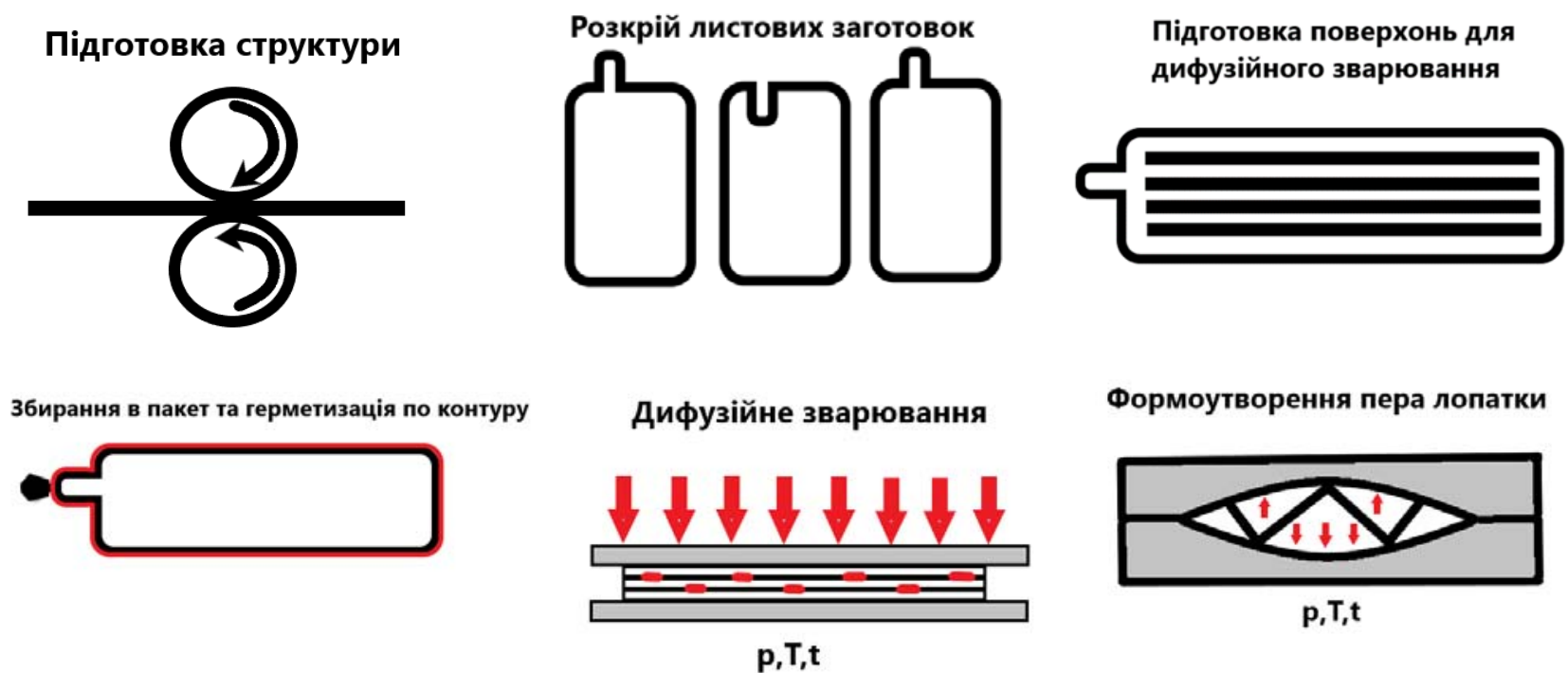

Формоутворення пера лопатки

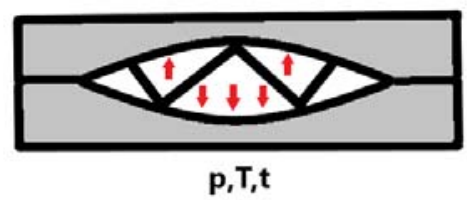

Рис. 6. Структурна схема виготовлення порожнистих лопаток

Спроектований пристрій призначений для дослідження деформування елементів порожнистої лопатки (рис. 7).

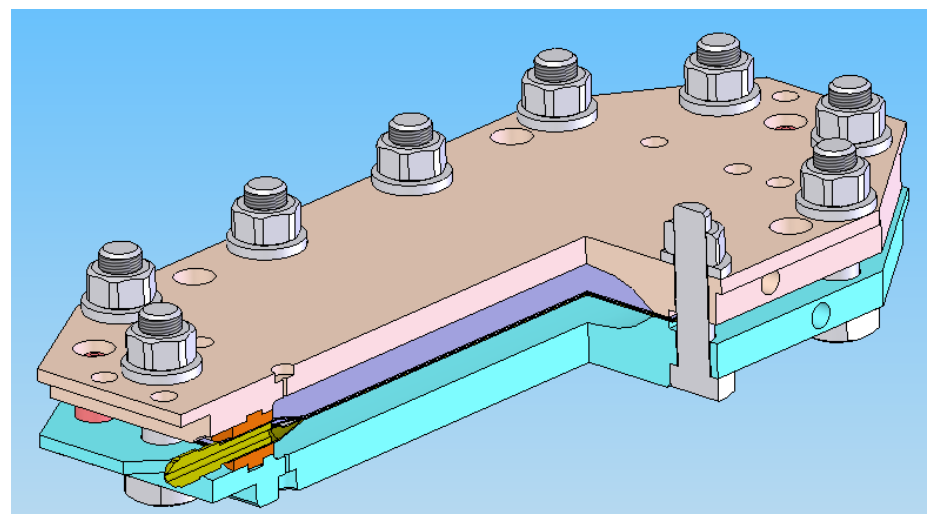

Рис. 7. Пристрій для дослідження деформування елементів порожнистої лопатки

Заготовки складаються з двох або трьох листів та штуцера, зварених по контуру. 
Заготовка збірна зі штуцером розміщається між матрицями, які приймають участь у формуванні зовнішньої поверхні лопаток, та між втулками. Колонки направляючі служать для правильної орієнтації одна відносно другої матриць. Все це міцно фіксується болтами та гайками 3 шайбами. Необхідність напіввтулок обумовлено різною товщиною заготовок та різним зовнішнім радіусом в заготовках в зоні штуцера. В матрицях є отвори для виходу повітря. Для укладання пристрою в піч можливо вкрутити в бокові різьбові отвори матриць гвинти або болти. При ускладненні роз'єднання матриць після нагрівання, в верхній матриці передбачено 4 технологічних різьбових отвори.

Заготовка в пристрої розташовується в пічці та нагрівається до певної температури. Через штуцер подається під тиском газ аргон, в результаті чого формується порожниста лопатка. Середній лист формує перегородки.

\section{ВИСНОВКИ}

Аналітично з використанням комп'ютерної системи CAD/CAEANSYS доведено, що порожниста металева лопатка вентилятора гофрового типу при роботі витримає значні великі статичні, вібраційні та температурні напруження та наповнювач виконує роль демпфера коливань. Був аналітично проведений порівняльний аналіз з моделлю вентиляційної лопатки конкретного профілю, що знаходиться в льотній експлуатації. Отримані результати були прийняті в якості критерію при проведенні подальшого чисельного моделювання. Хвостову частину лопатки 3 математичної моделі виключили, для спрощення. Був проведений статичний та модальний аналіз для кожного варіанту математичної моделі. Аналіз показав, що рівень напружень в моделі порожнистої лопатки від прикладених навантажень нижче, ніж в суцільній робочій лопатці вентилятора.

Відпрацювання технологічного процесу виготовлення порожнистої лопатки типової форми поперечного перерізу виконано для фрагменту пера лопатки обмеженої довжини та співвідношенням $\frac{L}{B} \geq 3$. Спроектовано пристрій для дослідження формоутворення фрагменту деформування елементів порожнистої лопатки.

Запропоновано структуру технологічного процесу виготовлення порожнистих лопаток, яка включає операції нанесення захисного покриття на поверхні заготовок, збирання заготовок в пакет, герметизування пакета по кромкам, зварювання під тиском та формоутворення пера лопатки в ізотермічних умовах.

\section{СПИСОК ВИКОРИСТАНОЇ ЛІТЕРАТУРИ}

1. Богуслаев В. А., Муравченко Ф. М. и др. Технологическое обеспечение эксплуатационных характеристик деталей ГТД. Лопатки компрессора и вентилятора. Часть 1. Запорожье : ОАО «Мотор Сич», 2003.420 с.

2. Тітов В. А., Гараненко Т. Р. Конструкторсько - технологічні рішення типових елементів порожнистих лопаток. Проблеми тертя та зношування. 2019. Вип. 3(84). С. 69-75.

3. Корыгин А. А., Багров С. В., Пятунин К. Р. Разработка конструкции моноколеса вентилятора с полыми лопатками для ТРДД высокой степени двухконтурности. Электронный журнал «Труды МАИ». 2011.45. URL: $\quad$ http://trudymai.ru/upload/iblock/688/razrabotka-konstruktsii-monokolesa-ventilyatora-s-polymi-lopatkamidlya-trdd-vysokoy-stepeni-dvukhkonturnosti.pdf?lang=ru\&issue=45 (дата звернення: 15.03.2018).

4. Потапов С. Д., Перепелица Д. Д. Обеспечение прочностной надежности полой широкохордной лопатки вентилятора с учетом особенностей этапов ее жизненного цикла. Двигатель. 2010. Вип. 5. С. 30 -33.

5. Слободкина Ф. А., Малинин В. В., Малинин А. В. Оптимизация формы лопатки газовой турбины методами математического моделирования. Двигатель. 2011. Вип. 5. С. 28-30.

6. Ахунов А. Х., Дмитриев С. В., Сафиуллин Р. В., Сафиуллин А. Р. и др. Расчет полей перемещений трехслойных полых конструкций для неразрушающего контроля качества методом цифровой голографической интерферометрии. Письма о материалах. 2012. т. 2. С. 90-94.

7. Кайбышев О. А., Галимов А. К., Круглов А. А., Лутфуллин Р. Я. и др. Численный анализ вариантов конструкции пустотелой вентиляторной лопатки. Проблемы машиностроения и надежности машин. 2004. 1. С. 90-95.

8. Нихамкин М. Ш., Любчик О. Л. Теоретические коэффициенты концентрации напряжений в полых лопатках вентилятора с повреждениями. Вестник ПНИПУ. Аэрокосмическая техника. 2012. Вип. 32. С. $25-35$.

9. Павлов В. П., Нусратуллин Э. М., Филиппов А. А. Прочность лопатки компрессора авиационного двигателя при замене титанового сплава на композиционный матеріал. Вестник УГАТУ. Уфа. 2011. Вип. 4. С. 98-106. 
10. Гусев Ю. А., Сиренко Ф. Ф., Бабиито Н., Бойко В. В. Анализ напряженно-деформированного и динамического состояния широкохордной лопатки вентилятора ТРДД. Вестник двигателестроения. 2010. Вип. 2. C. 109-113.

11. Каплун А. Б., Морозов Е. М., Олферьева М. А. ANSYS в руках инженера: Практическое руководство. Москва: Книжный дом «ЛИБРОКОМ», 2015. 272 с.

12. Биргер И. А., Шорр Б. Ф., Иосилевич Г. Б. Расчет на прочность деталей машин: Справочник. 4-е изд. перераб. и доп. Москва : Машиностроение, 1993. 640 с.

13. Гараненко Т. Р., Прибора Т. И., Березовский Е. К. Численное исследование широкохордных полых рабочих лопаток вентилятора. Вестник двигателестроения. 2016. Вип. 1. С. 18-23.

14. Pat. 1754857. Europe. Hollow fan blade detail half, hollow fan blade for turbine engine and corresponding manufacturing method. Weisse Michael A. United Technologies Corporation Hartford. 2012.

15. Pat. 0568201B1. Europe. A method of manufacturing an article by superplastic forming and diffusion bonding. John Owen Nelson, Richardson Brian Coln, ROLLS-ROYCE plc London. 1996.

16. Пейтон Н. Е. Сверхпластическая формовка конструкционных сплавов: пер. с англ. А. А. Алалыкина, А. М. Африкантова, А. И. Новикова. Москва : Металлургия, 1985. 312 с.

\section{REFERENCES}

1. Boguslaev V.A., Muravchenko F.M. et al. Technological support for operational characteristics of gas turbine engine parts. Blades of the compressor and fan. Part 1. Zaporizhzhya: JSC "Motor Sich". 2003,420 p. (in Russian).

2. Titov V.A., Garanenko T.R. Design and technological solutions of typical elements of hollow blades. Problems of friction and wear. 2019, 3 (84), pp. 69-75. (in Ukrainian).

3. Korygin A.A., Bagrov S.V., Pyatunin K.R. Development of the design of a monowheel of a fan with hollow blades for turbofan engines of a high degree of bypass ratio. Electronic journal "Transactions of MAI" [Online]. 2011, 45. http://trudymai.ru/upload/iblock/688/razrabotka-konstruktsii-monokolesa-ventilyatora-s-polymi-lopatkamidlya-trdd-vysokoy-stepeni-dvukhkonturnosti.pdf?lang=ru\&issue=45 (in Russian).

4. Potapov S.D., Quail D.D. Ensuring the strength reliability of a hollow broad-chord fan blade, taking into account the features of the stages of its life cycle. Engine. 2010, 5, pp. 30-33. (in Russian).

5. Slobodkina F.A., Malinin V.V., Malinin A.V. Optimization of the shape of a gas turbine blade by mathematical modeling. Engine. 2011, 5, pp. 28-30. (in Russian).

6. Akhunov A.X., Dmitriev S.V., Safiullin R.V., Safiullin A.R., Safin F.F. Calculation of the displacement fields of three-layer hollow structures for non-destructive quality control by digital holographic interferometry. Letters on materials. 2012, T. 2, pp. 90-94. (in Russian).

7. Kaybyshev O.A., Galimov A.K., Kruglov A.A., Lutfullin R.Ya., Safiullin R.V. Numerical analysis of design options for a hollow fan blade. Problems of mechanical engineering and machine reliability. 2004, 1, pp. 90-95. (in Russian).

8. Nihamkin M.Sh., Lubchik O.L. Theoretical stress concentration factors in hollow fan blades with injuries. Bulletin of PNIPU, Aerospace Engineering. 2012, 32, pp. 25-35. (in Russian).

9. Pavlov V.P., Nusratullin E.M., Filippov A.A. The strength of the compressor blade of an aircraft engine when replacing a titanium alloy with a composite material. Bulletin of USATU. Ufa. 2011, 4, pp. 98-106. (in Russian).

10. Gusev Yu.A., Sirenko F.F., Babiito N., Smartly V.V. Analysis of the stress-strain and dynamic state of a broad-chord fan blade of a turbofan engine. Bulletin of engine building. 2010, 2, pp. 109-113. (in Russian).

11. Kaplun A.B., Morozov E.M., Olferieva M.A. ANSYS in the hands of an engineer: A practical guide. Moscow: Book House "Librocom". 2015, 272 p. (in Russian).

12. Birger I.A., Shorr B.F., Iosilevich G.B. Strength analysis of machine parts. Handbook. Moscow: Mechanical Engineering. 1993, 640 p. (in Russian).

13. Garanenko T.R., Pribora T.I., Berezovsky E.K. Numerical study of wide-chord hollow fan blades. Bulletin of engine building. 2016, 1, pp. 18 - 23. (in Russian).

14. Pat. 1754857 Europe. Hollow fan blade detail half, hollow fan blade for turbine engine and corresponding manufacturing method. Weisse Michael A., United Technologies Corporation Hartford. 2012.

15. Pat. 0568201B1 Europe. A method of manufacturing an article by superplastic forming and diffusion bonding. John Owen Nelson, Richardson Brian Coln. ROLLS-ROYCE plc. London. 1996.

16. Peyton N.E. Superplastic forming of structural alloys. Trans. from English A.A. Alalykin, A.M. Afrikantov, A.I. Novikov. Moscow: Metallurgy. 1985, 312 p. (in Russian).

Гараненко Т. Р. - асистент НТУУ «КПІ ім. І. Сікорського».

НТУУ «КПІ ім. І. Сікорського» - Національний технічний університет України «Київський політехнічний інститут імені Ігоря Сікорського», м. Київ.

E-mail: tetiana.garanenko@gmail.com 